\title{
Could the Ear Be the Avenue to A Surprising Syndrome
}

\author{
Hala I EL Gendy*and Gehad G Maghraby \\ Department of Internal Medicine, Cairo, Egypt \\ *Corresponding author: HalaIbrahem El Gendy, Department of Internal Medicine, Cairo University, Egypt
}

ARTICLE INFO

Received: 㓞 July 29, 2020

Published: August 07, 2020

Citation: Hala I EL Gendy, Gehad G Maghraby. Could the Ear Be the Avenue to A Surprising Syndrome. Biomed J Sci \& Tech Res 29(3)-2020. BJSTR. MS.ID.004794.

$\begin{array}{lll}\text { Keywords: } & \text { Rheumatic } & \text { Heart } \\ \text { Disease; } & \text { Acute } \quad \text { Rheumatic } & \text { Fever; }\end{array}$ Pathogenesis;Complications; Management

\section{ABSTRACT}

Background: Keutel syndrome is a rare autosomal recessive characterized by diffuse cartilage calcification, brachytelephalangism, peripheral pulmonary artery stenoses and facial dysmorphism, occurs as a result of MGP mutations

Case Report: We present a case of keutel syndrome with bilateral sensory neural deafness, calcification of the cartilage tracheobronchial rings, ear cartilage,aortic root ascending and descending aorta, pulmonary artery with bilateral pulmonary artery branchs stenosis.

Conclusion: In such cases often the cause of haring loss and abnormal faces with wide spreadcartilage calcification possibility of keutel syndrome must raise.

\section{Case Report}

We present a 13-year-old female patient, positive consanguinity, at the age of four, patient's mother noticed diminution of her daughter hearing power of gradual onset and progressive course,no ear discharge, pain, or neurologic manifestations. On ENT consultation,she was diagnosed as having bilateral sensory neural deafness more on left side,ear grommet's tubes were inserted with partial improvement.

She suffered recurrent ear infection for which left myringoplasty was done.

1. However stridor with failure of tube removal when she was operated upon,this helps to diagnose subglottic stenosis and tracheostomy tube was inserted.She referred to our medical department for depressed nasal bridge,abnormal features,subglottic stenosis for further evaluation.

On examination normal vital signs with short stature, midface retrusion, stiff and rigid ears,saddle nose,short terminal phalanges(Figure 1).

IQ test, 75 (borderline) most probably due to hearing problems ,harsh ejection systolic murmur over pulmonary and aortic .Her blood tests were unremarkable, serum calcium, phosphorus and alkaline phosphatase levels in serum were within normal ranges, X-ray lateral view neck revealed, calcification in all tracheal rings,(Figure 2).Ct scan neck and chest revealed faint mural calcification is seen along the tracheobronchial tree \&calcific focus of pulmonary artery and semilunar faint calcification in ascending aorta,(Figure 3).Ct scan of petrous bone revealed calcification in ear cartilage.(Figure 4).ehocardiography revealed aortic stenosis ,heavily calcified aortic root, ascending and descending aorta, bilateral branch pulmonay stenosis measured $0.4 \mathrm{~cm}$ with peak and mean gradients (45\&31) mmHg on the left branch and (34\&23) on the right branch \& right ventricular hypertrophy.

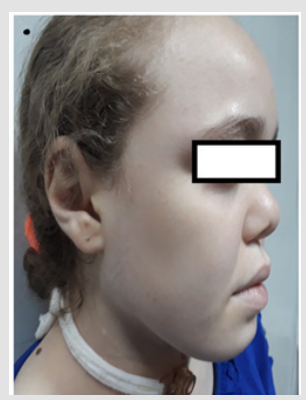

Figure 1: Patient with elongated face with maxillary and midface hypoplasia, hypoplasia alae nasi. 


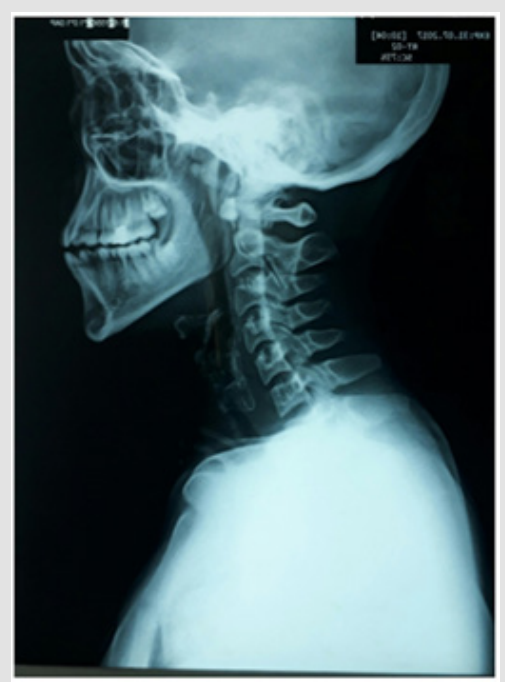

Figure 2: Calcification in all tracheal rings.

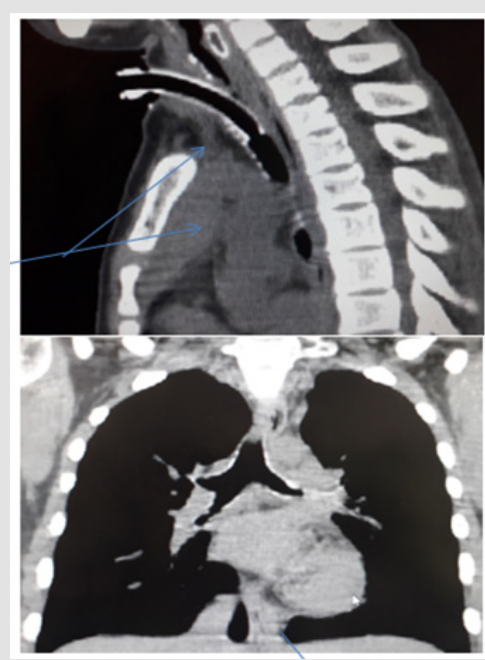

Figure 3: Mural calicification is seen along the tracheobronchial tree.

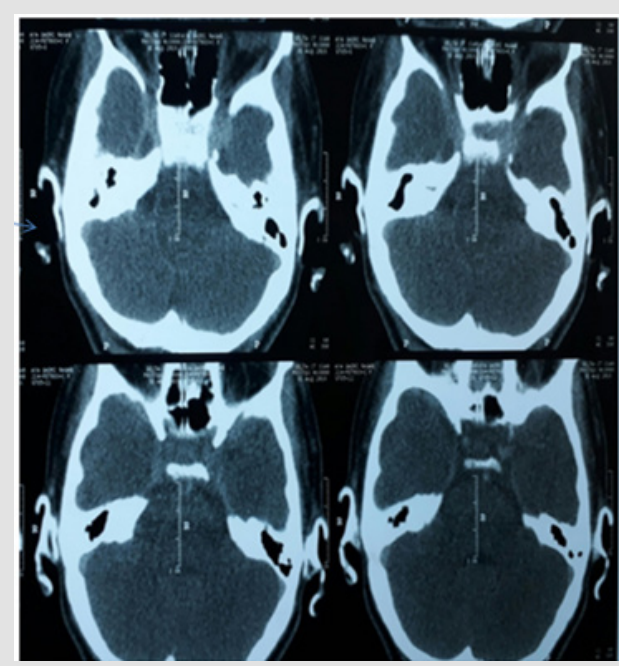

Figure 4: calcification in ear cartilage.

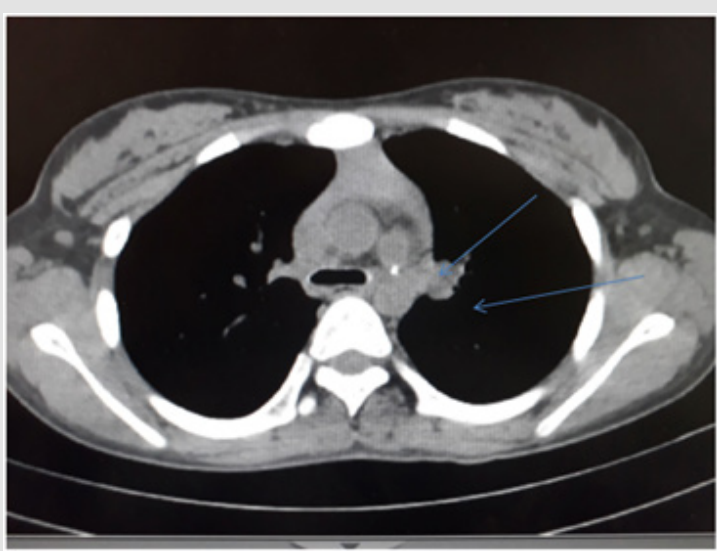

Figure 5: Calcific focus of pulmonary artery and semilunar faint calcification in ascending aorta.

\section{Discussion}

Hearing loss has many causes in children as infections,maternal drug and congenital,[1].Laryngotracheobronchial calcification is a rare finding in children under 13 years old [2]. Tracheobronchial calcifications can occur in Keutel syndrome, congenital cardiac abnormalities, chondrodysplasia punctata syndrome, and warfarin sodium therapy or rarely it can be idiopathic [3]. Keutel syndrome is an autosomal recessive disorder caused by a novel loss-of-function mutation in the Matrix Gla Protein gene (MGP). MGP protein resides in the extracellular matrix and is implicated in inhibiting calcification though the repression of bone Morphogenetic Protein 2 (BMP2). Mutations resulting in loss of consensus donor splice site at exon 2-intron 2 junctions result in significant diffuse calcification of soft tissue cartilage. Arterial calcification resulting from MGP inactivation results in prognosis, commonly seen in patients with diabetes, atherosclerosis, and renal dysfunction[4-6]. In conclusion, in such cases often the cause of haring loss and abnormal faces with wide spread cartilage calcification possibility of keutel syndrome must raised.

\section{Conflict of Interest}

The author declares no financial support and no conflict of interest.

\section{References}

1. Meier M, Weng LP, Alexandrakis E, Rüschoff J, Goeckenjan G (2001) Tracheobronchial stenosis in Keutel syndrome Eur Respir J 17: 566-569.

2. Canalis RF, Lambert PR (2000) The ear: Comprehensive otology. Lippincott Williams \& Wilkins, Philadelphia, USA.

3. Hoeffel JC, Bretagne MC, Thollot F (1998) Calcification of the laryngeal, tracheal, and bronchial cartilages in children. Am J Dis Child 142(10): 1024-1026.

4. Hur DJ, Raymond GV, Kahler SG, Riegert-Johnson DL, Cohen BA, et al. (2005) A Novel MGP Mutation in a Con- sanguineous Family: Review of the Clinical and Molecular Characteristics of Keutel Syndrome. Am J Med Genet A 135(1): 36-40.

5. Munroe PB, Olgunturk RO, Fryns JP, Van Maldergem L, Ziereisen F, et al. (1999) Mutations in the gene encoding the human matrix Gla protein cause Keutel syndrome. Nat Genet 21: 142-144. 
6. Xu L, Xia Z, Liu X, Huang S (2012) A case of Keutel syndrome in child (review the literature). Lin Chung Er Bi Yan Hou Tou Jing Wai Ke Za Zhi 26(18): 793-794.

ISSN: 2574-1241

DOI: $10.26717 /$ BJSTR.2020.29.004794

Hala I EL Gendy. Biomed J Sci \& Tech Res

(c) (P) This work is licensed under Creative

Submission Link: https://biomedres.us/submit-manuscript.php

$\begin{array}{ll}\text { BIOMEDICAL } & \text { Assets of Publishing with us } \\ \text { RESEARCHES } & \text { - Global archiving of articles } \\ \text { - Immediate, unrestricted online access } & \text { - Rigorous Peer Review Process } \\ & \text { - Authors Retain Copyrights } \\ & \end{array}$

